\title{
PENGARUH JENIS MEDIA ORGANIK TERHADAP KUALITAS BIBIT TAKIR (Duabanga moluccana)
}

\author{
The Effect of Organic Media Type on the Quality of \\ Takir (Duabanga moluccana) Seedling
}

\author{
Kurniawati Purwaka Putri dan/and Nurhasybi \\ Balai Penelitian Teknologi Perbenihan Bogor \\ Jln. Pakuan, Ciheuleut, P.O. Box 105 Bogor, Telp./Fax : 0251- 8327768
}

\begin{abstract}
Takir (Duabanga moluccana) is a pioneer and fast growing species that is prospective to be planted in the forest plantation. Seedling procurement for this species is still using natural material that will have negative effect to the environmental. This research was aimed at finding the influence of organic media to the growth of takir (D. moluccana) at the age of 4 months. The design of the research used completely randomized design consists of 3 treatments of transplanting (mix of saw dust and compost (1:1); (mix of soil, rice husk, and compost (1:2:1); (mix of soil, coconut husk, and compost (1:2:1)). Every treatmenst were having 3 repititions, each consist of 12 seeds. Parameter that observed are seedling's height, seedling's diameter, total biomass, top root ratio and seedling quality index. The results indicated that until the age of 4 months, seeds that applied in organic media are a mixture of soil, coconut husk and compost (1:2:1) produce the best of heigth (21.6 centimetres) and dry weigth total (11.0 grams), even though different with (1:1) saw dust and compost mixed media which are 19.9 centimetres and 10.9 grams. The highest top root ratio on mixed media of soil, saw dust, and compost are 1.16. For takir seedling can use organic coumpounds of saw dust and compost (1:1) as a substitute media for top soil.
\end{abstract}

Keywords : Compost, coconut husk, organic media, rice husk, saw dust, takir (Duabanga moluccana)

\begin{abstract}
ABSTRAK
Takir (Duabanga moluccana) merupakan jenis pionir cepat tumbuh dan memiliki prospek untuk dikembangkan dalam hutan tanaman. Pengadaan bibit masih banyak menggunakan tanah top soil sebagai media tumbuh yang dikhawatirkan akan merusak lingkungan. Penelitian ini bertujuan untuk mengetahui pengaruh penggunaan media organik terhadap pertumbuhan dan kualitas bibit takir. Rancangan penelitian yang digunakan adalah rancangan acak lengkap dengan tiga macam media (campuran serbuk gergaji dan kompos (1:1); campuran tanah, arang sekam padi dan kompos (1:2:1); campuran tanah, serbuk sabut kelapa dan kompos (1:2:1)). Setiap perlakuan menggunakan 3 ulangan, masing-masing terdiri dari 12 bibit. Parameter yang diamati adalah tinggi bibit, diameter batang, berat kering total, rasio pucuk akar dan indeks mutu bibit. Hasil penelitian menunjukkan sampai umur 4 bulan bibit takir yang ditumbuhkan pada media campuran tanah, serbuk sabut kelapa dan kompos
\end{abstract}


(1:2:1), menghasilkan pertumbuhan tinggi $(21,6 \mathrm{~cm})$ dan berat kering total bibit (11 gram) terbaik, walaupun tidak berbeda nyata dengan media campuran serbuk gergaji dan kompos (1:1) yaitu sebesar 19,9 cm dan 10,9 gram. Rasio pucuk akar tertinggi dihasilkan pada media campuran tanah, serbuk sabut kelapa dan kompos (1:2:1) sebesar 1,16. Untuk pembibitan takir dapat digunakan campuran bahan organik serbuk gergaji dan kompos (1:1) sebagai media pengganti top soil.

Kata kunci : Arang sekam padi, media organik, kompos, sabut kelapa, serbuk gergaji, takir (Duabanga moluccana)

\section{PENDAHULUAN}

Mutu bibit di persemaian diantaranya dipengaruhi secara langsung oleh kondisi media tempat tumbuhnya. Media tumbuh mempunyai peranan penting dalam memenuhi berbagai keperluan kebutuhan hidup tanaman yaitu memberi dukungan mekanik dengan menjadi tempat berjangkarnya akar, menyediakan ruang untuk pertumbuhan dan perkembangan akar, serta menyediakan udara untuk respirasi, air dan hara (Putri dan Djam'an, 2004). Media tumbuh yang umum digunakan dalam pembibitan adalah tanah lapisan atas (top soil). Top soil tersusun atas komposisi alamiah dengan kandungan mineral yang sangat berguna bagi tanaman. Namun terdapat beberapa kelemahan dari penggunaan top soil sebagai media sapih, diantaranya media sapih lekas menjadi padat, aerasi kurang baik karena mengandung bahan organik sedikit dan ketersediaan unsur hara tertentu bagi tanaman yang sangat kurang (Hendromono, 1988). Selain itu Schmidt (2000) menyebutkan bahwa kelemahan penggunaan tanah sebagai media bibit adalah banyaknya kandungan patogen, sehingga sering dihadapi masalah penyakit seperti dumping off. Oleh karena itu diperlukan adanya media tambahan atau media pengganti yang mempunyai sifat lebih baik untuk pertumbuhan bibit tanaman hutan, seperti bahan-bahan organik yang banyak berada di sekitar lingkungan kita.

Penggunaan bahan organik seperti serbuk sabut kelapa, serbuk gergaji, gambut, atau arang sekam padi sebagai media tambahan atau media pengganti top soil diketahui dapat menambah ketersediaan unsur hara di dalam tanah, memperbaiki struktur tanah, meningkatkan kapasitas tukar kation, memperbesar kemampuan tanah menahan air, membantu mengurangi toksinitas ion alumunium, meningkatan drainase dan aerasi tanah serta memperbaiki aktivitas mikroorganisme tanah (Danu et al., 
2006). Manfaat penggunaan media organik yang penting lainnya adalah untuk mencegah semakin berkurangnya lapisan top soil yang subur dan mengurangi penggunaan bahan yang dapat merusak lingkungan.

Duabanga moluccana (Takir) adalah jenis tanaman potensial sebagai salah satu jenis prioritas dalam pembangunan hutan tanaman. Jenis tanaman yang memiliki bentuk batang lurus ini bersifat pionir karena mampu tumbuh dengan cepat, memiliki daur hidup yang pendek dan mudah tumbuh pada lahan-lahan terbuka sisa penebangan di hutan-hutan alam. Keunggulannya yang lain adalah sifat fisik, mekanis dan penampilan kayunya yang baik sehingga memiliki nilai ekonomis tinggi (Surata, 2007; Martawijaya et al., 1989). Dari hasil penelitian Surata (2007) dilaporkan bahwa rata-rata tinggi tanaman takir umur 10 tahun mencapai $15,35 \mathrm{~m}$ dengan diameter $31,28 \mathrm{~cm}$, serta menghasilkan volume kayu sebesar 131,56 $\mathrm{m}^{3} / \mathrm{ha}$. Dalam rangka pengembangan tanaman takir ini sangat diperlukan dukungan informasi teknik budidaya terutama untuk teknik persemaiannya, karena kualitas bibit yang dihasilkan di persemaian akan menentukan keberhasilan penanaman di lapangan.

Penelitian ini dilakukan dengan tujuan untuk mengetahui pengaruh penggunaan media organik terhadap pertumbuhan dan kualitas bibit takir (Duabanga moluccana) yang berumur 4 bulan.

\section{BAHAN DAN METODE}

\section{A. Lokasi dan Waktu Penelitian}

Penelitian ini dilaksanakan di Persemaian Balai Penelitian Teknologi Perbenihan di Bogor pada bulan Agustus sampai bulan Desember 2002.

\section{A. Bahan dan Alat}

Bahan yang digunakan dalam penelitian ini antara lain : buah takir (Duabanga moluccana) yang diunduh dari kebun percobaan Haurbentes Jawa Barat, tanah lapisan atas (top soil), pasir, sekam padi, serbuk sabut kelapa, serbuk gergaji dan kompos hasil perombakan serasah atau sisa tanaman. Sedangkan alat-alat yang digunakan antara lain karung, kantong plastik, plastik transparan, shading net, label, kamera, alat-alat ukur, kaliper, penggaris, oven, desikator, cawan petri, serta timbangan analitik. 


\section{B. Metode Penelitian}

Pengunduhan dilakukan untuk semua buah yang sudah masak fisiologis yang dicirikan oleh warna buah coklat kehitaman. Ekstraksi buah takir dilakukan dengan cara mengeringkan buah di bawah sinar matahari selama 1- 2 hari sampai buah merekah dan keluar benihnya. Benih ditabur di atas media yang telah disiram sampai jenuh kemudian bak tabur ditutup dengan plastik transparan selama 2 minggu. Cara penaburan benih yaitu dengan mencampurkan benih dan pasir halus terlebih dahulu sebelum benih ditaburkan di atas media. Media perkecambahan yang digunakan adalah campuran pasir dan tanah halus $(1: 1)$ yang telah disterilkan. Penyiraman dilakukan setiap hari sekali dengan sprayer yang halus selama \pm 1 bulan.

Setelah berumur 3 bulan dari penaburan, bibit kemudian disapih ke polybag berukuran 10 x $12 \mathrm{~cm}$ yang telah berisi media sesuai dengan perlakuan yang diberikan. Kriteria kecambah siap sapih adalah kecambah yang telah memiliki dua pasang daun (kecambah normal). Persemaian dinaungi shading net dengan intensitas cahaya $50 \%$. Pemeliharaan di persemaian berupa penyiraman dan pembersihan gulma. Penyiraman dilakukan setiap hari bila hari tidak hujan, sedangkan pembersihan gulma dilakukan secara berkala apabila terdapat gulma yang tumbuh dalam kantong plastik.

Rancangan penelitian yang digunakan adalah Rancangan Acak Lengkap dengan 3 perlakuan media organik yang terdiri dari :

A1 = Serbuk gergaji : kompos, perbandingan $1: 1(\mathrm{v} / \mathrm{v})$;

A2 = Tanah $:$ arang sekam padi $:$ kompos, perbandingan $1: 2: 1(\mathrm{v} / \mathrm{v})$;

A3 = Tanah : serbuk sabut kelapa $:$ kompos, perbandingan $1: 2: 1(\mathrm{v} / \mathrm{v})$.

Dalam penelitian ini digunakan 3 ulangan masing-masing terdiri dari 12 bibit.

Parameter yang diamati dalam penelitian ini meliputi : tinggi bibit, diameter batang, berat kering total, rasio pucuk akar dan indeks mutu bibit. Rasio pucuk akar adalah perbandingan antara berat kering pucuk dan berat kering akar sedangkan nilai Indeks Mutu Bibit diperoleh dengan menggunakan rumus Dickson et al. (1960).

Analisis data yang dilakukan adalah analisis keragaman. Jika hasil analisis keragaman tersebut menunjukkan perbedaan yang nyata, maka analisa dilanjutkan dengan Uji Jarak Berganda Duncan (DMRT). 


\section{HASIL DAN PEMBAHASAN}

Perlakuan penggunaan media organik sebagai media sapih bibit takir berpengaruh nyata terhadap pertumbuhan tinggi dan berat kering total serta berpengaruh sangat nyata terhadap nisbah pucuk akar. Perlakuan yang diberikan tidak berpengaruh nyata terhadap diameter dan indeks mutu bibit takir.

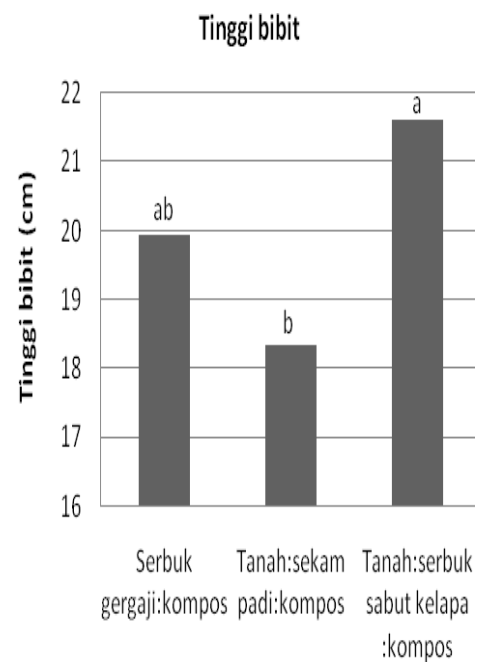

A

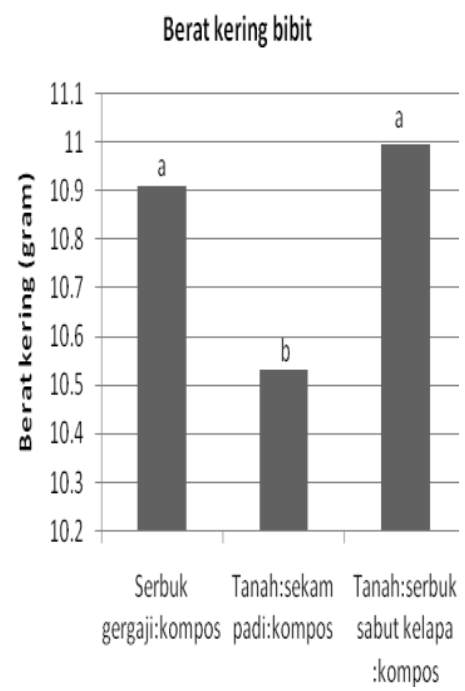

b

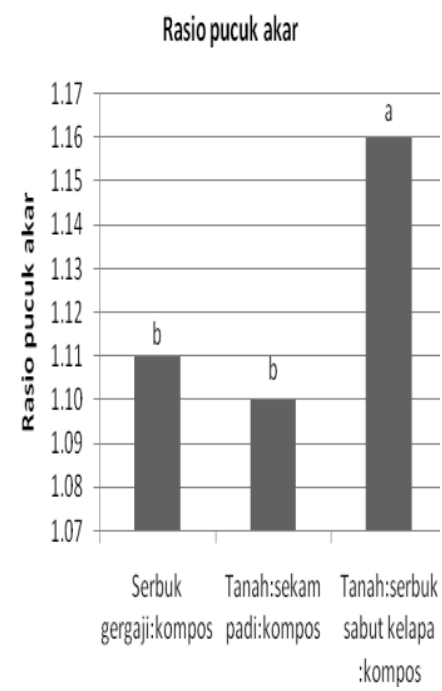

c

Gambar (Figure) 1. Pertumbuhan tinggi (a), berat kering total (b) dan rasio pucuk akar (c) bibit takir (height growth (a), dry weight (b) and top root ratio(c) of takir's seedling)

Hasil uji lanjut seperti pada Gambar 1 menunjukkan bahwa penambahan bahan organik serbuk sabut kelapa dan kompos ke media top soil menghasilkan bibit takir dengan pertumbuhan tinggi $(21,6 \mathrm{~cm})$ dan berat kering total (11 gram) tertinggi, dan tidak berbeda secara nyata dengan pertumnbuhan tinggi dan berat kering total bibit yang ditumbuhkan pada media campuran serbuk gergaji dan kompos yaitu sebesar $19,9 \mathrm{~cm}$ dan 10,9 gram.

Berat kering total mencerminkan akumulasi senyawa organik yang berhasil disintesis tanaman dari senyawa anorganik (unsur hara, air dan karbohidrat), semakin tinggi berat kering total menunjukkan semakin baik pertumbuhan bibitnya. Berdasarkan hasil tersebut diduga serbuk sabut kelapa dan kompos yang ditambahkan kedalam media tanah mampu memperbaiki struktur tanah, sehingga tanah menjadi remah dan gembur serta memiliki kemampuan menyimpan air (draenasi) dan 
porositas udara (aerasi) yang baik. Sutater et al. (1998) dalam Pramono dan Djam'an (2000) dan Hendromono (1988) menjelaskan bahwa serbuk sabut kelapa memiliki kapasitas memegang air yang tinggi $(66,61 \%)$ serta kerapatan lindak (bulk density) yang rendah. Kondisi fisik media tersebut sangat memungkinkan akar tanaman untuk berkembang biak dengan baik dan memiliki kondisi pasokan air yang cukup memadai.

Media organik lain yang juga terbukti mampu menghasilkan bibit takir dengan tingkat pertumbuhan yang cepat adalah campuran kompos serbuk gergaji + kompos serasah tanaman (1:1) yaitu sebesar 19,93 cm untuk tinggi bibit dan 10,9 gram untuk berat kering total. Hal ini menunjukkan bahwa bahan organik seperti kompos serbuk gergaji dapat dijadikan media alternatif dalam pembibitan. Montano et al. (1977) dalam Hendromono (1988) menyebutkan bahwa kandungan zat penghambat pertumbuhan pada media limbah kayu yang telah menjadi kompos adalah sangat kecil atau bahkan tidak ada. Selanjutnya dijelaskan bahwa serbuk gergaji mengandung semua unsur hara mikro yang diperlukan untuk pertumbuhan tanaman.

Tanaman akan mudah menyerap unsur hara yang terkandung dalam medianya, apabila media tanam memiliki kandungan $\mathrm{C} / \mathrm{N}$ rendah yang sesuai dengan $\mathrm{C} / \mathrm{N}$ mikroba sekitar 14. Kandungan $\mathrm{C} / \mathrm{N}$ dari media campuran tanah + serbuk sabut kelapa serta media kompos serbuk gergaji relatif masih tinggi yaitu berturut-turut sebesar 19,63 untuk media campuran tanah serbuk sabut kelapa dan 19,52 - 35,8 untuk media serbuk gergaji (tergantung jenis kayunya) (Kurniaty, 2006; Kurniaty, 2007; Putri, 2008). Hal ini menandakan bahwa jumlah unsur hara yang dapat diserap tanaman cukup rendah, sehingga menyebabkan lambatnya pertumbuhan tanaman. Pertumbuhan bibit yang lambat akibat rendahnya tingkat serapan hara dalam media organik juga terjadi pada bibit suren (Toona sinensis) dan Shorea balangeran, dimana media campuran tanah + serbuk sabut kelapa dan media organik serbuk gergaji menghasilkan bibit dengan tingkat pertumbuhan yang lambat (Hani, 2007; Siahaan et $a l ., 2004)$. Oleh karena itu dalam penelitian ini dilakukan penambahan kompos hasil perombakan serasah atau sisa tanaman dalam media sapih takir untuk meningkatkan unsur hara dalam media sapih takir. Mindawati (1998) menyatakan bahwa untuk menurunkan kandungan $\mathrm{C} / \mathrm{N}$ dalam media tanam adalah dengan menambahkan bahan kompos yang mengandung $\mathrm{C} / \mathrm{N}$ rendah seperti pupuk hijau, kotoran ternak atau penambahan organik dalam bentuk pupuk organik maupun pupuk anorganik. Penambahan kompos hasil perombakan serasah atau sisa tanaman kedalam media 
campuran tanah + serbuk sabut kelapa dan media organik serbuk gergaji inilah yang diduga kuat turut mendukung keberhasilan pertumbuhan bibit takir.

Sekam padi juga dapat dimanfaatkan sebagai media pendukung atau pengganti top soil yang baik karena memiliki kapasitas mengikat air yang tinggi yaitu sebesar 12,3\% (Ruswendi, 2004). Danu et al. (2006) melaporkan bahwa media top soil + arang sekam padi + pupuk kandang dengan komposisi 1:1:1 memberikan pertumbuhan tinggi dan diameter anakan sentang yang terbaik, dimana pertumbuhan tinggi anakan meningkat sebanyak 73,85\% dibandingkan dengan anakan pada media top soil saja. Namun demikian, dalam penelitian ini penggunaan sekam padi sebagai media campuran tanah belum menunjukkan hasil yang menggembirakan. Pertumbuhan tinggi dan berat kering total dari bibit takir pada media campuran tanah : sekam padi : kompos $(1: 2: 1)$ adalah yang terendah $(18,33 \mathrm{~cm} ; 10,5$ gram $)$. Hal tersebut diduga karena sekam padi yang digunakan dalam penelitian ini kurang terdekomposisi secara sempurna, sehingga tanaman kurang mendapatkan nitrogen cukup yang ditandai dengan pertumbuhannya yang lambat, walaupun sudah diberikan tambahan unsur hara melalui kompos hasil perombakan serasah atau sisa tanaman sekalipun. Kemungkinan lainnya adalah diduga komposisi arang sekam padi yang diberikan terlalu banyak sehingga cenderung menurunkan pertumbuhan tinggi bibit. Arang sekam padi memiliki kapasitas mengikat air cukup yang tinggi, tetapi tidak menjamin bahwa semakin banyak arang sekam padi yang digunakan akan memberikan hasil yang lebih baik. Siahaan et al. (2004) melaporkan bahwa pada bibit belangeran terlihat adanya kecenderungan penurunan pertumbuhan tinggi bibit dengan semakin banyaknya media organik dalam media.

Rasio pucuk akar dari bibit takir yang ditumbuhkan pada media campuran tanah : arang sekam padi : kompos $(1,11)$ dan media campuran serbuk gergaji : kompos $(1,10)$ lebih kecil dibandingkan dengan rasio pucuk akar dari bibit yang ditumbuhkan pada media campuran tanah : serbuk sabut kelapa : kompos $(1,16)$. Namun demikian dilihat dari besaran rasio pucuk akar yang dihasilkan, bibit takir yang ditumbuhkan pada ketiga macam media tersebut telah siap untuk dipindahkan ke lapangan.

Kualitas bibit serta kesiapan bibit untuk dapat ditanam ke lapangan diantaranya juga dapat dilihat dari nilai Indeks Mutu Bibit (Menurut Lankey dan Alm, 1982 dalam Hendromono dan Durachin, 2004). Indeks mutu bibit yang semakin tinggi menandakan semakin tinggi kualitas morfologis bibitnya (Hendromono, 1995). Hasil 
penelitian menunjukkan bahwa media sapih tidak berpengaruh nyata terhadap indeks mutu bibit takir. Hal tersebut menandakan bahwa kualitas bibit takir yang ditumbuhkan pada ketiga media tersebut relatif sama dengan rata-rata indeks mutu bibit mencapai 0,25. Penggunaan serbuk sabut kelapa sebagai media tambahan tanah top soil juga terbukti mampu menghasilkan bibit eboni umur 9 bulan dengan kualitas yang tidak berbeda (indeks mutu bibit sebesar 1,18) dengan bibit yang ditumbuhkan pada media tanah murni sama (indeks mutu bibit sebesar 0,15) (Durachim dan Hendromono, 2006). Penggunaan serbuk gergaji atau serbuk kelapa sebagai media pencampur top soil juga terbukti mampu menghasilkan bibit Acacia mangium dengan kualitas yang lebih baik (nilai indeks mutu bibit tinggi) dibandingkan bibit yang ditumbuhkan pada media bahan organik murni saja (Hendromono, 1988).

Implikasi dari hasil penelitian ini adalah media organik berupa serbuk gergaji, arang sekam padi atau serbuk sabut kelapa dengan tambahan kompos dapat dijadikan sebagai media campuran atau media pengganti top soil sebagai media dalam pembibitan takir. Pada prinsipnya media tumbuh tersebut harus mampu memberikan dukungan bagi kelangsungan hidup tanaman seperti aerasi yang baik, mampu menahan air dan menyediakan hara bagi pertumbuhan tanaman.

\section{KESIMPULAN}

1. Media campuran tanah, serbuk sabut kelapa dan kompos (1:2:1) menghasilkan pertumbuhan tinggi dan berat kering total bibit takir (Duabanga moluccana) terbaik (21,6 cm; 11 gram), dan tidak berbeda nyata dengan yang dihasilkan media campuran bahan organik serbuk gergaji dan kompos serasah tanaman $(19,9$ cm; 10,9 gram).

2. Campuran bahan organik serbuk gergaji dan kompos serasah tanaman dapat digunakan sebagai media pengganti top soil dalam pembibitan takir. 


\section{DAFTAR PUSTAKA}

Danu, D.J. Sudradjat, Verawati dan E. Suhardi. 2006. Pengaruh Komposisi Media terhadap Pertumbuhan Bibit Sentang (Azadirachta excelsa (Jack) Jacob) Asal Cabutan di Persemaian) dalam Prosiding Seminar Hasil-Hasil Penelitian Balai Litbang Teknologi Perbenihan "Teknologi Perbenihan untuk Pengadaan Benih Bermutu”. Bogor. $109-116$ p.

Dickson, A., A.L. Leaf dan J.F. Hosner. 1960. Quality Appraisal of White Spruce and White Pine Seedling Stocks in Nurseries. Forest. Chron. 36 (1) : 10-13.

Durahim dan Hendromono. 2006. Pengaruh Media dan Pupuk NPK terhadap Pertumbuhan dan Mutu Bibit Eboni (Diospyros celebica). Jurnal Penelitian Hutan dan Konservasi Alam Volume III (1) : 9 - 17.

Hani, A. 2007. Pertumbuhan Surian (Toona sinensis) asal Sukabumi, Tasikmalaya dan Ciamis pada Berbagai Media Sapih dalam Prosiding Workshop Sintesa Hasil Litbang Hutan Tanaman. Pusat Penelitian dan Pengembangan Hutan Tanaman. Bogor. $135-139 \mathrm{p}$

Hendromono. 1988. Meningkatkan Pertumbuhan dan Mutu Bibit Acacia mangium Willd dengan menggunakan Berbagai Macam Medium. Buletin Penelitian Hutan Vol. 502 . Pusat Penelitian dan Pengembagan Hutan. Bogor. 17 - 26 p.

Hendromono. 1995. Pertumbuhan dan Indeks Mutu Bibit Eucalyptus deglupta Blume pada Berbagai Suhu Udara dan Tingkat Naungan. Buletin Penelitian Hutan No $58: 1-12$.

Kurniaty, R., Budi Budiman dan Made Suartana. 2006. Pengaruh Media dan Naungan terhadap Kualitas Bibit. Laporan hasil penelitian BPTP, Bogor. Tidak diterbitkan

Kurniaty, R., B. Budiman, M. Suartana dan R.U. Damayanti. 2007. Pengaruh Media dan Naungan terhadap Kualitas Bibit. Laporan Hasil Penelitian BPTP, Bogor. Tidak diterbitkan.

Martawijaya, A.A., I. Kartasudjana, Y.I. Mandang, S.A. Prawira dan K. Kadir. 1989. Atlas Kayu Indonesia Jilid I. Badan Penelitian dan Pengembangan Kehutanan. Bogor.

Mindawati, N. 1998. Pengaruh Beberapa Macam Limbah Organik terhadap Mutu dan Proses Pengomposan dengan Bantuan Efektif Mikroorganisme 4 (EM4). Buletin Penelitian Hutan 614 :29-46. Bogor.

Pramono, A.A. dan D.F. Djam'an. 2000. Pengaruh Media dan Kondisi Lingkungan Perkecambahan terhadap Daya Berkecambah dan Pertumbuhan Berkecambah Benuang Bini (Octomeles sumatrana Miq). Buletin Teknologi Perbenihan Vol. $7(2): 1-10$. 
Putri, K.P dan D.F. Djam'an. 2004. Peran Manajemen Persemaian dalam Upaya Penyiapan Bibit Berkualitas. Info Benih Vol. 9 (1) : 13 - 26.

Putri, A.I. 2008. Pengaruh Media Organik terhadap Indeks Mutu Bibit Cendana. Jurnal Penelitian Hutan Tanaman. Vol. 2 (1) : 139 - 148.

Schmidt, L. 2000. Pedoman Penanganan Benih Tanaman Hutan Tropis dan Sub Tropis. Direktorat Jenderal Rehabilitasi Lahan dan Perhutanan Sosial, Dephut Bekerjasama dengan Indonesia Forest Seed Project (IFSP). Jakarta.

Siahaan, H., N.A Ulya, Nasrun, A.B. Lukman, J. Muara. 2004. Pengaruh Media Tumbuh dan Intensitas Naungan terhadap Pertumbuhan Bibit Belangeran. Jurnal Penelitian Hutan Tanaman Vol. 1 (3) : 125 - 131.

Surata, I. K. 2007. Uji Coba Penanaman Duabanga (Duabanga moluccana Blume) dengan Sistem Tumpangsari di Rarung, Provinsi Nusa Tenggara Barat. http://www.forda-mof.org/informasi.asp?kategoriid=62\&rootid=13\&page=4 . Diakses pada tanggal 19 Maret 2009. 
Lampiran (Appendix) 1. Analisis keragaman pengaruh media sapih terhadap tinggi bibit, diameter bibit, rasio pucuk akar, berat kering bibit, dan indeks mutu bibit (Analysis variance of the effect of seedling media on the seedling height, seedling diameter, top-root ration, dry weight seedling and seedling quality index)

\begin{tabular}{|c|c|c|c|c|c|}
\hline $\begin{array}{c}\text { Parameter } \\
\text { (Parameters) }\end{array}$ & $\begin{array}{l}\text { Sumber Keragaman } \\
\text { (Source of variation) }\end{array}$ & $\begin{array}{l}\text { Derajat bebas } \\
\text { (Degrees of } \\
\text { freedom) }\end{array}$ & $\begin{array}{l}\text { Jumlah } \\
\text { kuadrat } \\
\text { (Number } \\
\text { of square) }\end{array}$ & $\begin{array}{c}\text { Kuadrat } \\
\text { tengah } \\
\text { (Mean of } \\
\text { square) } \\
\end{array}$ & $\begin{array}{l}\mathrm{F}_{\text {hitung }} \\
\left(F_{\text {value }}\right)\end{array}$ \\
\hline \multirow{3}{*}{$\begin{array}{l}\text { Tinggi } \\
\text { (seeding } \\
\text { height) }\end{array}$} & Media sapih & 2 & 80,044 & 40,022 & \multirow[t]{3}{*}{$2,278 *$} \\
\hline & Galat & 42 & 737,867 & 17,568 & \\
\hline & Total & 44 & 817,911 & & \\
\hline \multirow{3}{*}{$\begin{array}{l}\text { Diameter } \\
\text { (seedling } \\
\text { diameter) }\end{array}$} & Media sapih & 2 & 0,077 & 0,039 & \multirow[t]{3}{*}{1,867} \\
\hline & Galat & 42 & 0,867 & 0,021 & \\
\hline & Total & 44 & 0,944 & & \\
\hline \multirow{3}{*}{$\begin{array}{l}\text { Berat kering } \\
\text { total bibit } \\
\text { (total of } d r y \\
\text { weight } \\
\text { seedling) }\end{array}$} & Media sapih & 2 & 1,810 & 0,905 & \multirow[t]{3}{*}{$3,878 *$} \\
\hline & Galat & 42 & 9,803 & 0,233 & \\
\hline & Total & 44 & 11,614 & & \\
\hline \multirow{3}{*}{$\begin{array}{l}\text { Rasio pucuk } \\
\text { akar (top-root } \\
\text { ratio) }\end{array}$} & Media sapih & 2 & 0,033 & 0,016 & \multirow[t]{3}{*}{8,487 ** } \\
\hline & Galat & 42 & 0,082 & 0,002 & \\
\hline & Total & 44 & 0,115 & & \\
\hline \multirow{3}{*}{$\begin{array}{l}\text { Indeks mutu } \\
\text { bibit (seedling } \\
\text { quality index) }\end{array}$} & Media sapih & 2 & 0,025 & 0,012 & \multirow[t]{3}{*}{1,733} \\
\hline & Galat & 42 & 0,301 & 0,007 & \\
\hline & Total & 44 & 0,326 & & \\
\hline
\end{tabular}

Keterangan (Remarks): $* *=$ Berbeda sangat nyata pada selang kepercayaan $99 \%$ (Significantly different at $95 \%$ convident level) 